\title{
Decolorization of Anaerobically Digested Molasses Spentwash by Coagulation
}

\author{
Mrityunjay Singh Chauhan ${ }^{1}$, Anil Kumar Dikshit ${ }^{2,3,4, *}$ \\ ${ }^{1}$ Department of Civil Engineering, Maulana Azad National Institute of Technology, Bhopal, 462051, India \\ ${ }^{2}$ Centre for Environmental Science and Engineering, Indian Institute of Technology Bombay, Powai, Mumbai, 400076, India \\ ${ }^{3}$ School of Civil Engineering, Survey and Construction, University of KwaZulu-Natal, Durban, 4041, South Africa \\ ${ }^{4}$ School of Civil and Environmental Engineering, Nanyang Technological University, 639798, Singapore
}

\begin{abstract}
Treatment of molasses spentwash has always posed a challenge to the environmental engineers. Problem becomes more difficult in the countries like India where more harsh environmental parameters of spentwash on one hand and limitation of treatment cost on the other is crude reality. Inability to grow micro-organisms in undiluted spentwash further limits the options. In this work, various options of coagulation were tried as primary treatment to make spentwash fit for further biological treatment without dilution. Poly aluminium chloride(PAC) was found to be the best coagulant.
\end{abstract}

Keywords Coagulation, Decolorization, Distillery, Spentwash

\section{Introduction}

There are about 300 distilleries in India, producing about 2.75 billion litres of alcohol annually[1]. India is the fourth largest producer of ethanol in the world and the second largest in Asia. Though, the alcohol production from starchy material is also practiced on a very limited scale, most of the Indian distilleries use sugarcane molasses as raw material. About 4-10 kg of molasses is required for production of one litre of alcohol[2]. Apart from its use for beverage, medicinal, pharmaceutical and flavouring, alcohol constitutes the feedstock for large number of organic chemicals, which are used in manufacturing a wide variety of intermediates, drugs, rubber, pesticides, solvents etc.[3]. Distillery ranks as the top most industry among the list of 17 heavily polluting industries identified by Ministry of Environment \& Forests, Govt. of India, and are covered under Central Action Plan. Distillery spentwash is not only high on organic and inorganic loading, but also has dark brown colour even after industry standard treatment by anaerobic digestion/ bio-methanation. The anaerobically treated spentwash does not meet Central Pollution Control Board(CPCB) standards of discharge into streams or land application. Groundwater colorization is growing concern for areas having land application of distillery spentwash. Spentwash is toxic to aquatic organisms as $\mathrm{LC}_{50}$ value for distillery spentwash was found to be $0.5 \%$ for fresh water fish Cyprinus carpio var. Communis[4]. It behaves much

* Corresponding author:

dikshit@iitb.ac.in (Anil Kumar Dikshit)

Published online at http://journal.sapub.org/ajee

Copyright (C) 2012 Scientific \& Academic Publishing. All Rights Reserved more hazardously when disposed into water bodies, since it may result in the complete depletion of dissolved oxygen and aquatic life will be destroyed[5].

Rao et al. conducted laboratory scale studies on methods of removing color from distillery wastewater. Aluminium sulfate and ferric chloride were found very effective in color removal from anaerobically treated diluted molasses and distillery wastes[6]. Color removal of molasses based distillery effluent was studied by Migo et al[7] using a commercial inorganic flocculent, a polymer of ferric hydroxyl sulfate with a chemical formula of $\left[\mathrm{Fe}_{2}(\mathrm{OH})_{\mathrm{n}}\left(\mathrm{SO}_{4}\right)_{3-\mathrm{n} / 2}\right]_{\mathrm{m}}$. For decolorization of anaerobically digested spentwash combined chemical and biological methods were also tried[8]. The first treatment included calcium oxide and hydrogen peroxide. This was followed by second treatment, which involved hydrogen peroxide and microbes at $144 \mathrm{hrs}$ incubation. Goto et al.[9] reported super critical water oxidation(SCWO) of distillery wastewater for removal of its color. In this process, oxidation reaction took place in water above its critical point $\left(647^{\circ} \mathrm{K}, 22.1 \mathrm{MPa}\right)$. Experiments were carried out with different amounts of biopolymer chitosan. This gave decolorization of the order of $94 \%$ along with $93 \%$ reduction in COD. Ten times diluted distillery wastewater(COD as $2800 \mathrm{mg} / \mathrm{L})$ was used for experimentation[10]. Ozonation of distillery(yeast fermented beer) waste was also tried to evaluate the process in terms of organic matter removal and decolorization efficiencies. Ozone generation system used was based on the production of ozone from the reaction of oxygen with UV light[11]. Pikaev et al[12] carried out study on combined electron beam and coagulation method for treatment of molasses based distillery effluent. Nandy et al. 
did their study on a bio-methanation system as pre-treatment option comprising anaerobic fixed film reactors. This wascombined with subsequent concentration through Multiple Effect Evaporators(MEE), and concentrated effluent was used for bio-composting of press-mud for production of bio-manure[13]. Color removal from biologically pre-treated molasses spentwash(COD $4580 \pm 100 \mathrm{mg} / \mathrm{L}$ ) by chemical oxidation through ozone was investigated by Pena et al[14].

Electrochemical treatment of digested spentwash was carried out for removal of its color. Power consumption was reported as $1.13-4.93 \mathrm{kWh} / \mathrm{kg}$ of $\mathrm{COD}[15]$. Coca et al[16] studied efficiency of ozonation and effect of various operating parameters when it was used for decolorization of beet molasses fermentation wastewater. Performance of Fenton oxidation process was tested for decolorization of biologically treated effluent of baker's yeast industry[17]. Mane et al[18] studied application of chemically treated bagasse for treatment of distillery wastewater. A hybrid nanofiltration(NF) and reverse osmosis(RO) pilot plant was used to remove colour of the distillery wastewater[19].

These options were tried either on diluted and synthetic wastewater or they are energy and cost intensive. Coagulation is a very effective method of decolourisation and removal of solids from the wastewater. There are numerous references available in literature about use of common coagulants for industrial wastewater treatment. This paper addresses the pre-treatment in the form of cost effective option of coagulation of anaerobically digested molasses spentwash(ADMS) so that biological treatment can be given to it without any dilution.

\section{Materials and Methods}

\subsection{Wastewater}

The study has been carried out on actual wastewater collected from a nearby 30 KLD distillery, producing rectified sprit using sugarcane molasses as raw material. Anaerobically digested molasses spentwash(ADMS) was collected from the overflow of the anaerobic digester and was brought to the CESE, IIT Bombay and was stored at $4^{\circ} \mathrm{C}$ in cold room till experimentation.

\subsection{Colour Measurement}

Intensity of colour was measured in terms of absorbance at $475 \mathrm{~nm}$. Samples were diluted in $1 \mathrm{M}$ phosphate buffer to maintain $\mathrm{pH}$ of 7. Samples were centrifuged at 10,000 rpm for 10 minutes prior to absorbance determination, for eliminating hindrance due to suspended particulates in the sample. After that, the supernatant was diluted 100 times and the absorbance was measured using Thermo Spectronic visible spectrophotometer(Model Helios Epsilon, USA). Reduction in colour was estimated in terms of reduction in absorbance with reference to that of the control(original ADMS).

\subsection{COD}

COD was measured by closed reflux method using $\mathrm{HACH}$ COD digester(Model DRB 200, USA) as given in Standard Methods(APHA-AWWA-WEF, 2005). Samples were suitably diluted with distilled water.

\subsection{Other Parameters}

Tests for other parameters were carried out as per Standard Methods[20] for characterization of the ADMS and treated ADMS samples.

\subsection{Coagulation Studies}

In the present study, commonly available coagulants viz. ferrous sulphate, ferric sulphate, ferric chloride, calcium chloride, calcium oxide, calcium hydroxide, alum, potash alum and poly aluminium chloride were examined for their efficiency of decolourisation and COD reduction. To simulate field conditions, all the coagulants used were of laboratory grade, procured from local market.

Jar tests were performed on undiluted ADMS samples with coagulants. VELP Scientifica jar test apparatus(Model JLT6, France) was used. Six one litre samples were taken in six one litre beakers and flash mixed at $100 \mathrm{rpm}$ for 2 minutes followed by slow mixing at $20 \mathrm{rpm}$ for 30 minutes. After appropriate settling time varying from 1 to 8 hours, the supernatant samples were drawn for further analysis. First, the optimum $\mathrm{pH}$ was found on the basis of reduction in absorbance in the $\mathrm{pH}$ range 2 to 12 . Lime or $\mathrm{HCl}$ was used for $\mathrm{pH}$ correction. At optimum $\mathrm{pH}$, optimum dose was found out by varying dose of coagulant over a wide range.

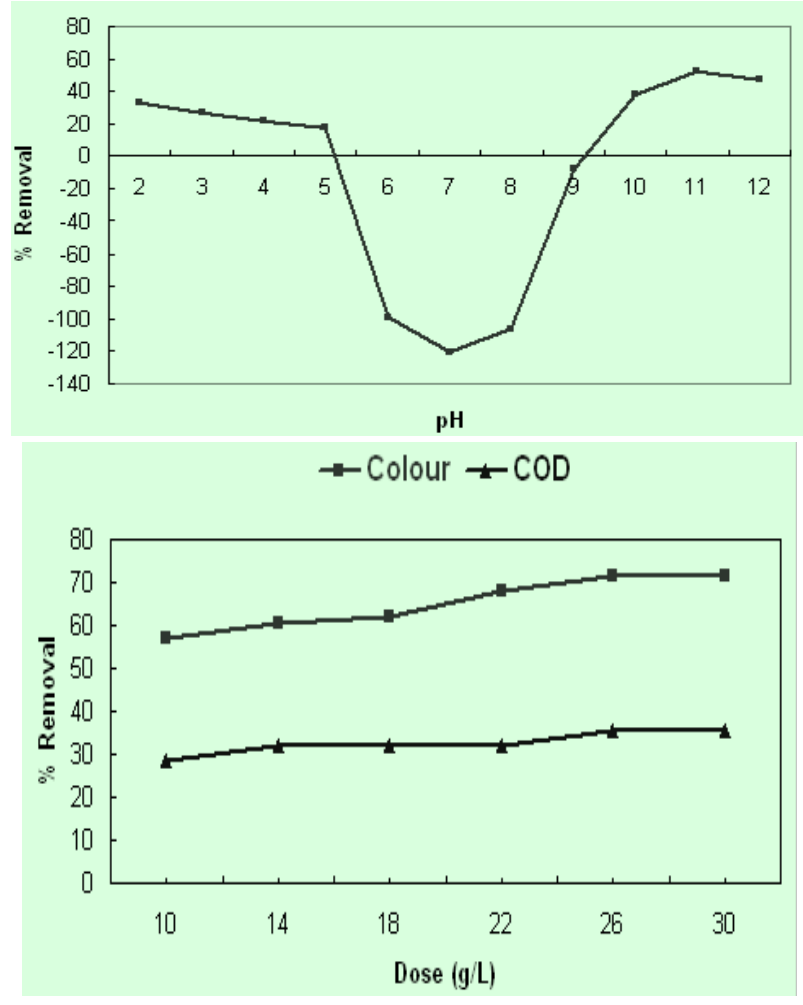

Figure 1. Colour Removal by Coagulation with Ferrous Sulfate 


\section{Results and Discussion}

Results of $\mathrm{pH}$ and dose optimization for various coagulants and spectra of 100 times diluted ADMS and coagulant treated ADMS are shown in following sections.

The optimum $\mathrm{pH}$ for ferrous sulfate was 11 and its dose of $26 \mathrm{~g} / \mathrm{L}$ gave reduction of $71 \%$ in colour and $36 \%$ in $\mathrm{COD}$ (Figure 1). Ferric chloride(Figure 2) is effective coagulant, widely reported in literature as this gives $\mathrm{Fe}^{3+}$ ions. Ferric chloride worked best at $\mathrm{pH}$ of 4 , giving $50 \%$ colour and $39 \%$ COD removal at $8 \mathrm{~g} / \mathrm{L}$. Figure 3 shows optimum $\mathrm{pH}$ for ferric sulfate which was also 4 and addition of $8 \mathrm{~g} / \mathrm{L}$ could achieve $43 \%$ reduction in colour with $28 \%$ reduction in COD. However, both the ferric salts were found to impart greenish colour to the treated sample. Even at smaller doses, although absorbance at standard wavelength $(475 \mathrm{~nm})$ was reduced but overall colour of the spentwash was worse than control.

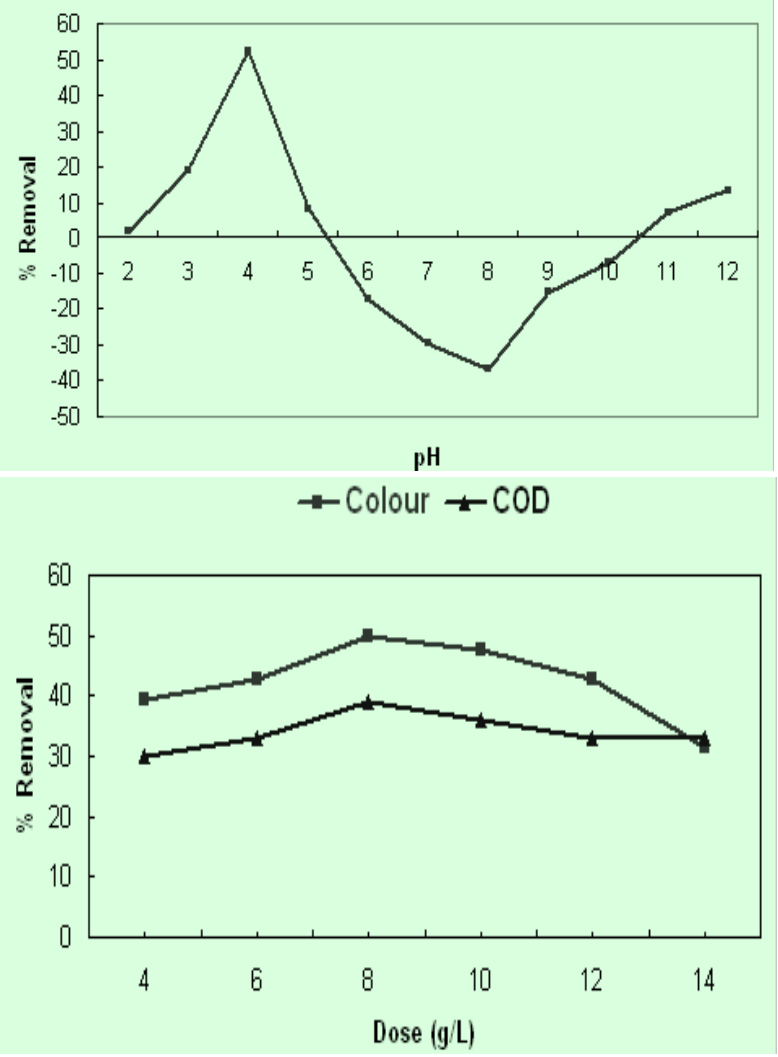

Figure 2. Colour and COD Removal by Coagulation with Ferric Chloride

At the optimum $\mathrm{pH}$ of 10 for calcium hydroxide, $46 \%$ reduction in colour with $32 \%$ reduction in COD was noticed at a dose of $14 \mathrm{~g} / \mathrm{L}$ (Figure 4$)$. The settling property of sludge was very poor with the volume of sludge generated being about $30 \%$ of total volume after 8 hours of settling. Calcium chloride when tested for its optimum $\mathrm{pH}$, to work as coagulant, showed different trend as compared to calcium hydroxide(Figure 5). The performance of calcium chloride was the best at $\mathrm{pH}$ of 12 and colour and COD reductions were $49 \%$ and $21 \%$, respectively at $18 \mathrm{~g} / \mathrm{L}$. In case of calcium oxide, optimum $\mathrm{pH}$ found was 11 . At about neutral $\mathrm{pH}(5$ to 8$)$, there was increase in the absorbance of the
ADMS(up to $48 \%$ at $\mathrm{pH}$ of 6 ). Maximum removal of $48 \%$ colour and $28 \%$ COD could be achieved with addition of 18 $\mathrm{g} / \mathrm{L}$ of calcium oxide(Figure 6).
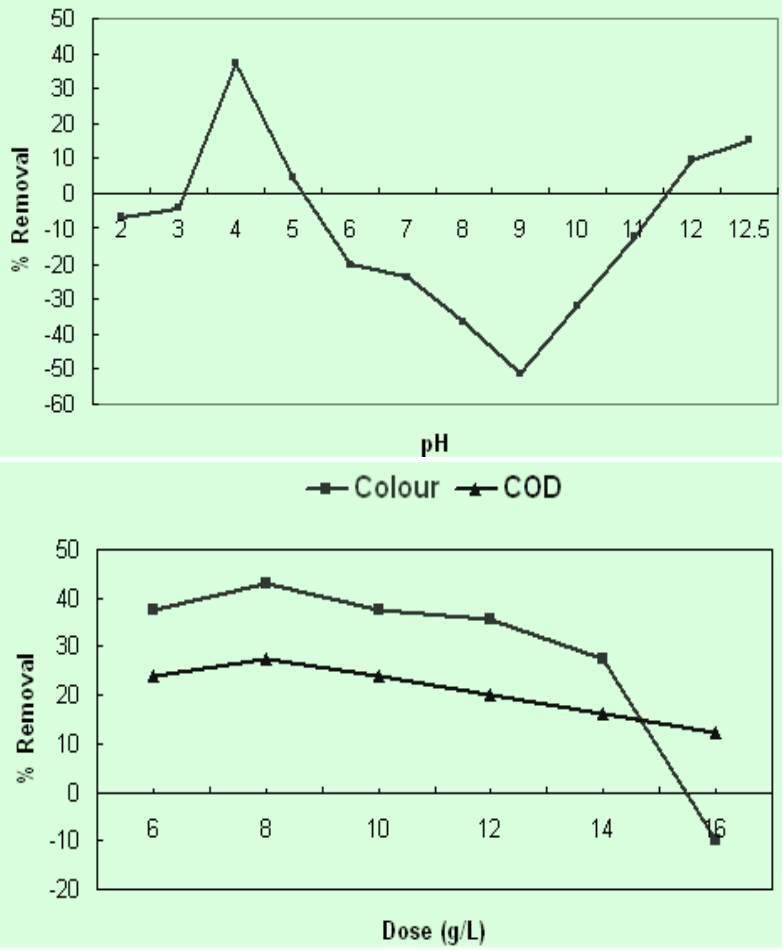

Figure 3. Colour and COD Removal by Coagulation with Ferric Sulfate
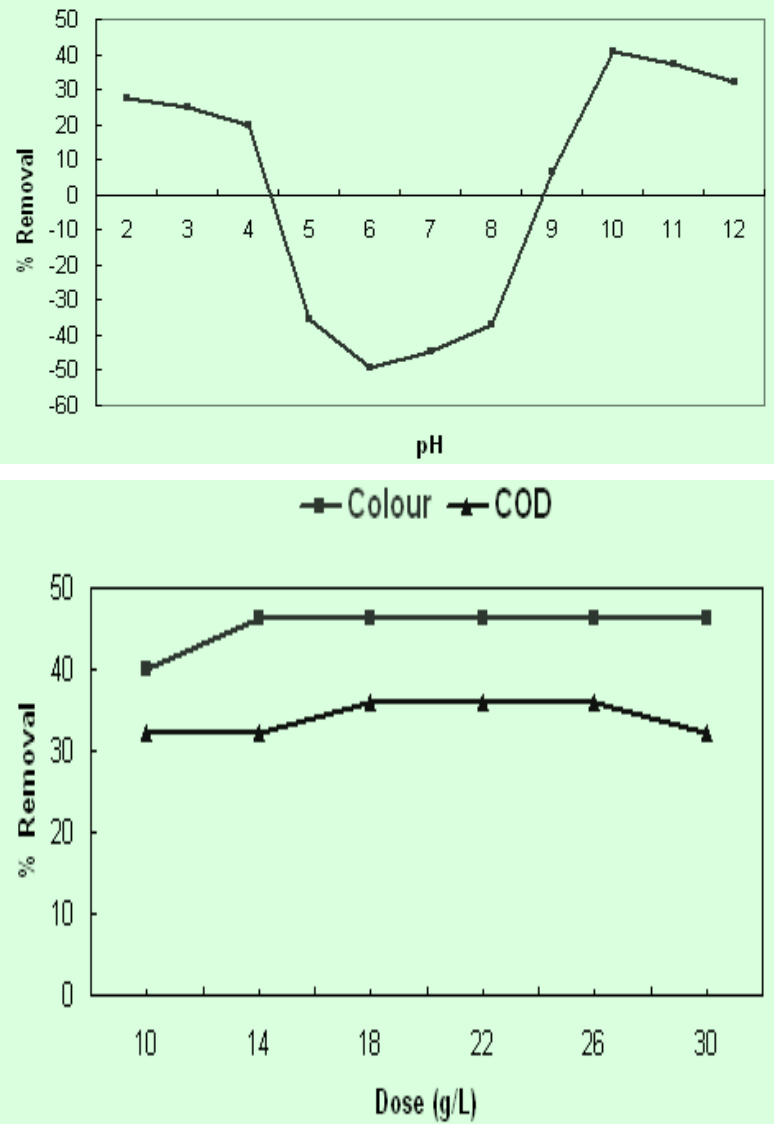

Figure 4. Colour and COD Removal by Coagulation with Calcium Hydroxide 


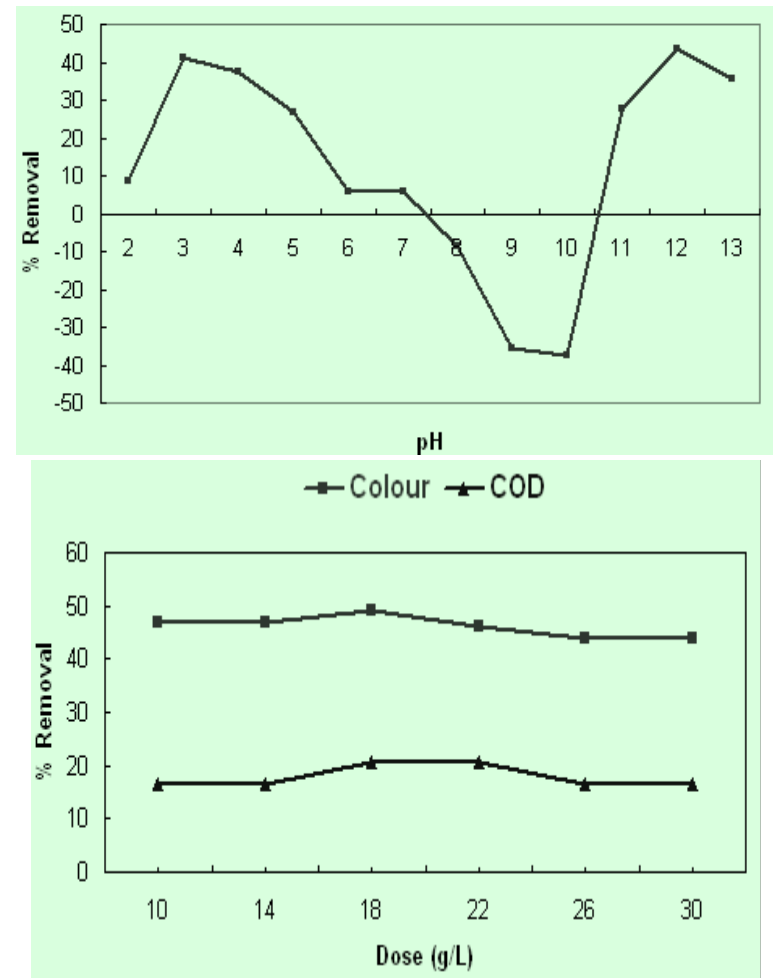

Figure 5. Colour and COD Removals by Coagulation with Calcium Chloride

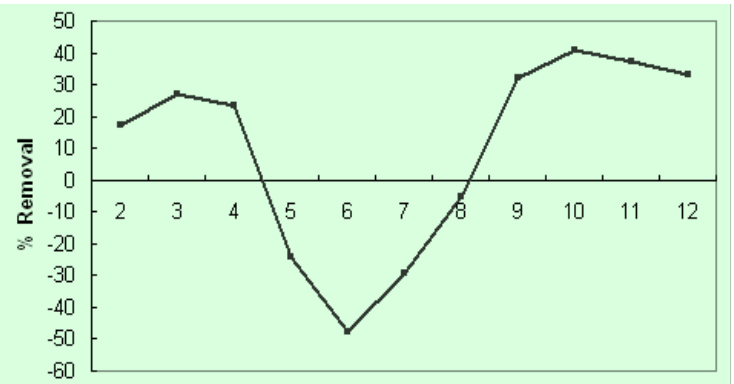

$\mathrm{pH}$

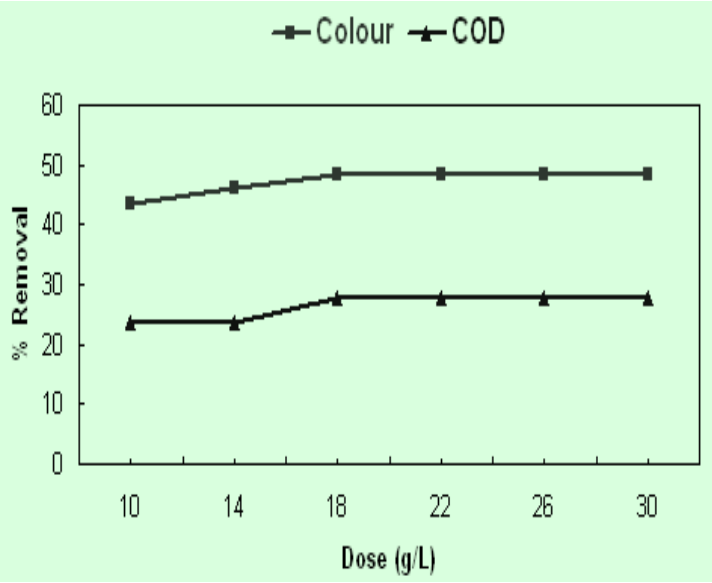

Figure 6. Colour Removal by Coagulation with Calcium Oxide

Potash alum(Figure 7) performed the best at the $\mathrm{pH}$ of 10. Maximum colour and COD reductions of $54 \%$ and $35 \%$ were seen at $22 \mathrm{~g} / \mathrm{L}$. Figure 8 shows that optimum $\mathrm{pH}$ for using alum as coagulant was 11 . When Alum was used, $61 \%$ and $31 \%$ reductions in colour and COD were achieved.
Based on colour and COD removal performance, ferrous sulphate and alum were selected for double coagulation study in combination with lime.
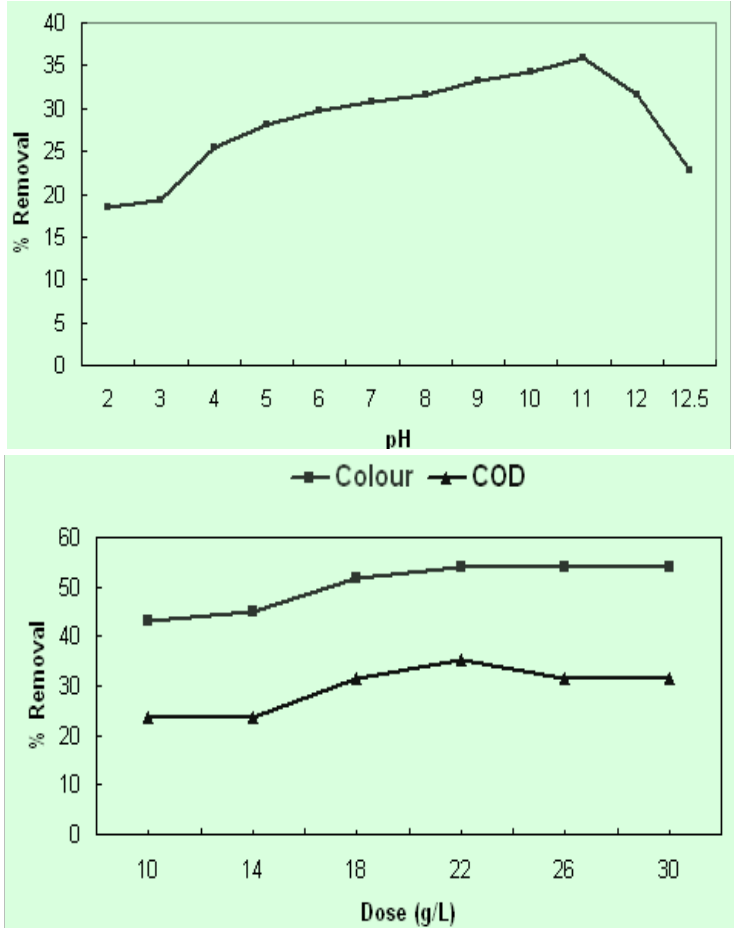

Figure 7. Colour and COD Removal by Coagulation with Potash Alum
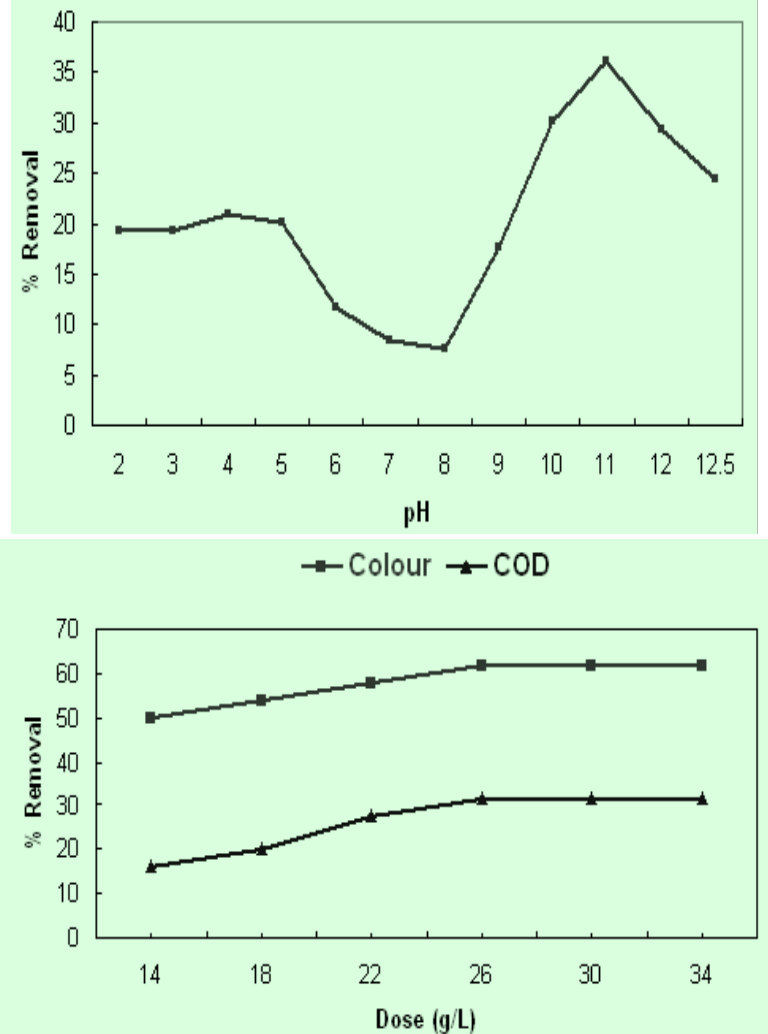

Figure 8. Colour and COD Removal by Coagulation with Alum

Commercially available coagulant poly aluminium chloride(PAC), which is reported to be very effective as well as economical for various industrial wastewaters, was also 
tried in this study. Poly aluminium chloride(PAC) worked at its best at the $\mathrm{pH}$ as 6(Figure 9). PAC removed $63 \%$ colour and $50 \%$ COD from the ADMS at dose of $8 \mathrm{~g} / \mathrm{L}$. A cationic flocculent-aid, Mahafloc, manufactured by M/s Ami chemicals, Vadodara was tried for assessing possibility of reducing dose of the PAC. The flocculent-aid could not reduce the total dose of the coagulant but the settling property of sludge improved and consequently total volume of sludge generated was reduced to about $20 \%$ as compared to about $30 \%$ without using flocculent-aid.
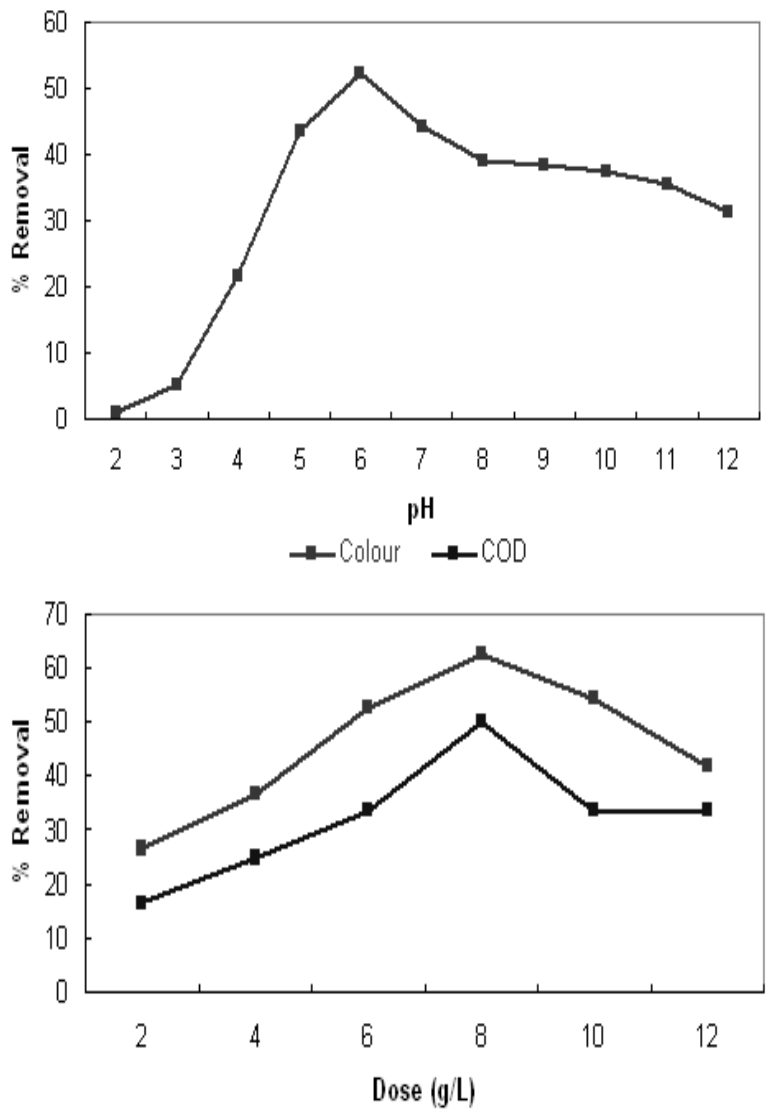

Figure 9. Colour and COD Removal by Coagulation with PAC

After single coagulation with ferrous sulphate, $\mathrm{pH}$ of ADMS dropped to 8.55 , which was adjusted to 11 by adding lime. At second stage coagulation, overall reduction in $83 \%$ in colour and $46 \%$ in COD was attained(Figure 10). The overall dose requirement was $40 \mathrm{~g} / \mathrm{L}$. The limitations of this option were again the same as those for lime, viz. high coagulant dose; excess sludge formation and high retention time due to poor sludge settling. At the first stage, sludge volume was found to be about $70 \%$ of the sample after $10 \mathrm{hrs}$ settling and $50 \%$ after $10 \mathrm{hrs}$ settling in the second stage. Hence, double coagulation can not be recommended as feasible pre-treatment option.

Single coagulation by alum gave about $60 \%$ reduction in colour with corresponding $30 \%$ reduction in COD at $26 \mathrm{~g} / \mathrm{L}$, however, the $\mathrm{pH}$ of the treated sample dropped to 7.55 after the coagulation. Again $\mathrm{pH}$ was increased to the optimum i.e. 11 and optimization of dose was done as shown in Figure 11.

At second stage, addition of $22 \mathrm{~g} / \mathrm{L}$ of alum gave overall reduction of $75 \%$ in colour and $39 \%$ in $\operatorname{COD}$ (Figure 11 ). Despite good results of removal, double coagulation could not emerge as pre-treatment option. Very high dose requirement viz. $48 \mathrm{~g} / \mathrm{L}$ renders the process uneconomical and other limitation of the double coagulation was the formation of excess sludge(about $60 \%$ of sample volume at first stage and about $50 \%$ at the second stage), hence, throughput was insignificant. Double coagulation with alum gave overall $75 \%$ colour and 39\% COD removals at overall dose of $48 \mathrm{~g} / \mathrm{L}$. High coagulant dose; excess sludge formation and high retention time due to poor sludge settling were found to be the limitations of the double coagulation. Hence, double coagulation could not be recommended as feasible pre-treatment option. Moreover, coagulation with ferric salts was dropped as they imparted greenish colour and coagulation with calcium salts was eliminated as the sludge produced showed extremely poor settling characteristics.

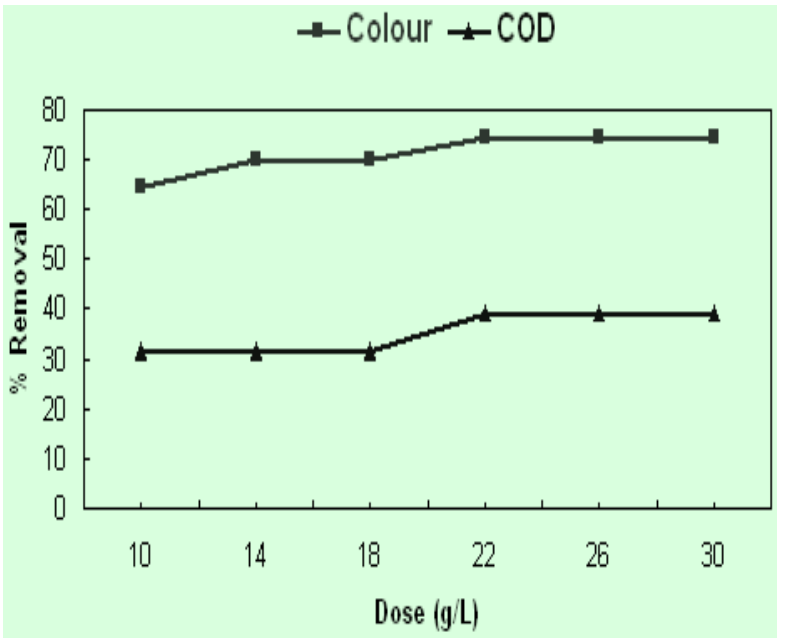

Figure 10. Colour and COD Removals at Different Doses of Alum at Second Stage in Double Coagulation

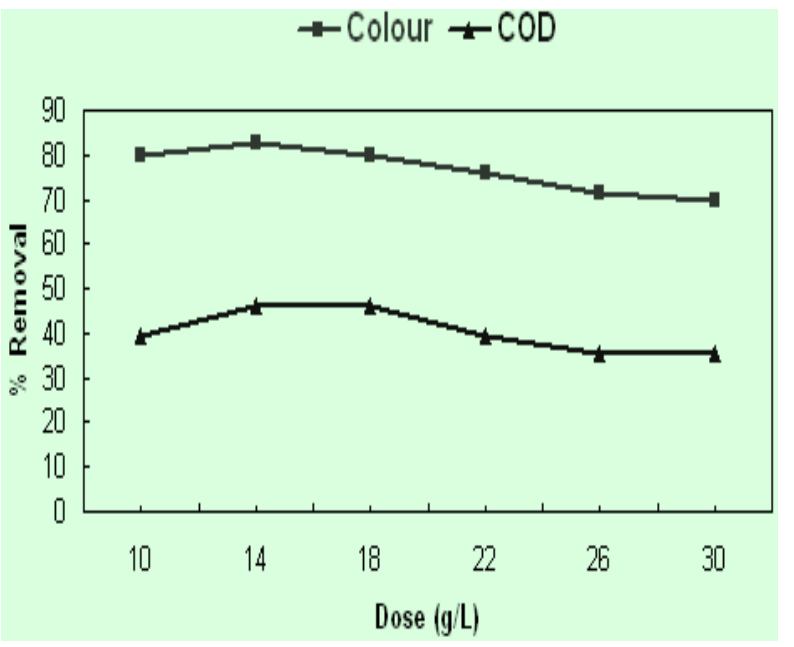

Figure 11. Colour and COD Removals at Different Doses of Ferrous Sulfate at Second Stage in Double Coagulation

Cost analysis of coagulation study shows that all the options are economically viable(with cost of treatment ranging between Rs. $0.052-0.458 / \mathrm{L} ; 1 \$=$ Rs.50). Table 1 presents summary of coagulation study along with their economics. 
Table 1. Summary of Coagulation Study

\begin{tabular}{|c|c|c|c|c|c|c|c|c|c|c|}
\hline \multirow[b]{2}{*}{ S. No. } & \multirow[b]{2}{*}{ Coagulant } & \multirow[b]{2}{*}{$\begin{array}{l}\text { Optimu } \\
\text { m } \\
\text { pH }\end{array}$} & \multirow[b]{2}{*}{$\begin{array}{c}\mathrm{pH} \\
\text { Adjusted } \\
\text { by }\end{array}$} & \multirow[b]{2}{*}{$\begin{array}{l}\text { Dose for } \mathrm{pH} \\
\text { Correction }\end{array}$} & \multirow[b]{2}{*}{$\begin{array}{l}\text { Dose of } \\
\text { Coagulant } \\
(\mathrm{g} / \mathrm{L})\end{array}$} & \multicolumn{2}{|c|}{$\%$ Reduction } & \multicolumn{3}{|c|}{ Cost of Treatment(Rs./L) } \\
\hline & & & & & & Color & COD & $\begin{array}{l}\text { For } \mathrm{pH} \\
\text { Correction }\end{array}$ & $\begin{array}{c}\text { For } \\
\text { Coagulatio } \\
\mathrm{n}\end{array}$ & Total \\
\hline 1 & Ferrous Sulfate & 11 & Lime & $15 \mathrm{~g} / \mathrm{L}$ & 26 & 71.4 & 35.7 & 0.030 & 0.169 & 0.199 \\
\hline 2 & Ferric Chloride & 4 & $\mathrm{HCl}$ & $18 \mathrm{~mL} / \mathrm{L}$ & 8 & 49.8 & 39.0 & 0.090 & 0.264 & 0.354 \\
\hline 3 & Ferric Sulfate & 4 & $\mathrm{HCl}$ & $18 \mathrm{~mL} / \mathrm{L}$ & 8 & 43.0 & 27.6 & 0.090 & 0.368 & 0.458 \\
\hline 4 & $\begin{array}{l}\text { Calcium } \\
\text { Hydroxide }\end{array}$ & 10 & Lime & $12 \mathrm{~g} / \mathrm{L}$ & 14 & 46.4 & 32.1 & 0.024 & 0.028 & 0.052 \\
\hline 5 & $\begin{array}{l}\text { Calcium } \\
\text { Chloride } \\
\end{array}$ & 12 & Lime & $18 \mathrm{~g} / \mathrm{L}$ & 18 & 49.2 & 20.8 & 0.036 & 0.234 & 0.270 \\
\hline 6 & Calcium Oxide & 10 & Lime & $12 \mathrm{~g} / \mathrm{L}$ & 18 & 48.4 & 27.6 & 0.024 & 0.180 & 0.204 \\
\hline 7 & Potash Alum & 11 & Lime & $15 \mathrm{~g} / \mathrm{L}$ & 22 & 54.1 & 35.2 & 0.030 & 0.176 & 0.206 \\
\hline 8 & Alum & 11 & Lime & $15 \mathrm{~g} / \mathrm{L}$ & 26 & 61.5 & 31.4 & 0.030 & 0.195 & 0.225 \\
\hline 9 & $\begin{array}{c}\text { Poly } \\
\text { Aluminium } \\
\text { Chloride } \\
\end{array}$ & 6 & $\mathrm{HCl}$ & $5 \mathrm{~mL} / \mathrm{L}$ & 8 & 62.5 & 50.0 & 0.025 & 0.200 & 0.225 \\
\hline 10 & $\begin{array}{c}\text { Double } \\
\text { Coagulation by } \\
\text { Alum } \\
\end{array}$ & 11 & Lime & $25 \mathrm{~g} / \mathrm{L}$ & 48 & 74.6 & 39.0 & 0.050 & 0.360 & 0.410 \\
\hline 11 & $\begin{array}{c}\text { Double } \\
\text { Coagulation by } \\
\text { Ferrous Sulfate }\end{array}$ & 11 & Lime & $22 \mathrm{~g} / \mathrm{L}$ & 40 & 82.5 & 46.4 & 0.044 & 0.260 & 0.304 \\
\hline
\end{tabular}

\section{Conclusions}

Coagulation of anaerobically digested molasses spentwash(ADMS) with poly aluminium chloride(PAC) was very promising pre-treatment option which not only removed organic loading and colour of the ADMS considerably but made it suitable for biological treatment also. Further studies on rendering the fungal treatment to such primarily treated ADMS without any dilution are under the way and are showing promising results.

\section{REFERENCES}

[1] AIDA(2008), Ethanol opportunities and challenges [Online] Available: http://aidaindia.org/its08/topics_covered.html

[2] Tewari, P. K., Batra, V. S. and Balakrishnan, M., 2007, Water management initiatives in sugarcane molasses based distilleries in India., Resources, Conservation and Recycling, $52,351-367$

[3] Mall, I.D., 1995, Waste utilization and management in sugar and distillery plants., Chemical Engineering World, XXX(1), 51-60

[4] Gupta, S.K., Anaerobic treatment options for distillery wastewater treatment, Proceedings of CEP Course on Distillery wastewater management: Achieving the goal of zero discharge at IIT Bombay, October 29- November 2, 2007

[5] Kumar, S. and Vishvanatham, L., 1991, Production of biomass, carbon dioxide, volatile acids and their interrelationship with decrease in chemical oxygen demand, during distillery waste treatment by bacterial strains., Enzyme Microbiology Technology,13, 179-187, 1991

[6] Rao, P.A.V.S., Karthikeyan, J. and Iyengar, L., Removal of color from distillery wastewater, Proceedings of the $44^{\text {th }}$ Purdue industrial waste conference, Purdue university, Indiana, pp 787-794, May 9-11, 1989

[7] Migo, P.V., Matsumura, M., Rosario, E.J.D. and Kataoka, H., 1993, Decolorization of molasses wastewater using an inorganic flocculent., Journal of Fermentation and Bioengineering, 75(6), 438-442

[8] Patil, N.B. and Kapadnish, B.P., 1995, Decolorization of melanoidin pigment from distillery spentwash., Indian Journal of Environmental Health, 37(2), 84-87

[9] Goto, M., Nada, T., Ogata, A., Kodama, A. and Hirose, T., 1998, Supercritical water oxidation for the destruction of municipal exceso sludge and alcohol distillery wastewater of molasses., Journal of Supercritical Fluids, 13, 277-282

[10] Lalov, I.G., Guirginov, I.I., Krysteva M. A. and Fartsov, K., 2000, Treatment of wastewater from distilleries with chitosan., Water Research, 34(5), 1503-1506

[11] Alfafara, C.G., Migo, V.P., Dallo, R.F. and Matsumura, M., 2000, Ozone treatment of distillery slop waste., Water Science and Technology, 42(3-4), 193-198

[12] Pikaev, A.K., Ponomarev, A.V., Bludenko, A.V., Minin, V.N. and Elizar'eva, L.M., 2001, Combined electron beam and coagulation purification of molasses distillery slops. Features of the method, technical and economical evaluation of large scale facility., Radiation Physics and Chemistry, 61, 81-87, 2001

[13] Nandy, T., Shastry, S. and Kaul, S.N., 2002, Wastewater management in cane molasses distillery involving bioresource recovery., Journal of Environmental Management, 65, 25-38

[14] Pena, M., Coca, M., Gonzalez, G., Rioja, R. and Garcia, M.T., 2003, Chemical oxidation of wastewater from molasses fermentation with ozone., Chemosphere, 51, 893-900

[15] Manisankar, P., Vishwanathan, N. and Rani, C., 2003, Electrochemical treatment of distillery effluent using catalytic 
anodes., Green Chemistry, 5, 270-274

[16] Coca, M., Pena, M. and Gonzalez, G., 2005, Variables affecting efficiency of molasses fermentation wastewater ozonation., Chemosphere, 60, 1408-1415

[17] Pala, A. and Erden, G., 2005, Decolorization of a baker's yeast industry effluent by Fenton oxidation., Journal of Hazardous Materials, B127, 141-148

[18] Mane, J.D., Modi, S., Nagwade, S., Phadnis, S.P. and Bhandari, V.M., 2006, Treatment of spentwash using chemically modified bagasse and colour removal studies., Bioresource Technology, 97(14), 1752-1755

[19] Nataraj, S.K., Hosamani, M. and Aminabhavi, M., 2006, Distillery wastewater treatment by the membrana-based nanofiltration and reverse osmosis processes., Water Research, 40, 2349-2356, 2006

[20] APHA-AWWA-WPCF, Standard methods for the examination of water and wastewater, American Public Health Association, $21^{\text {st }}$ Edition, New York, 2005 